\title{
VALORIZATION OF RAPESEED MEAL BY HYDROTHERMAL TREATMENT - EFFECT OF REACTION PARAMETERS ON LOW MOLECULAR PRODUCTS DISTRIBUTION
}

\author{
HANNA PIŃKOWSKA, ${ }^{*}$ MAŁGORZATA KRZYWONOS ${ }^{* *}$ and PAWEŁ WOLAK ${ }^{*}$ \\ "Wroctaw University of Economics, Department of Industrial Chemistry, \\ Komandorska 118/120, 53-345 Wroctaw, Poland \\ ${ }^{* *}$ Wrocław University of Economics, Department of Bioprocess Engineering, \\ Komandorska 118-120, 53-345 Wroctaw, Poland \\ \Corresponding author: M. Krzywonos, malgorzata.krzywonos@ue.wroc.pl
}

Received June 19, 2019

\begin{abstract}
The hydrothermolysis of rapeseed meal suspensions in subcritical water, as a method of its valorization, was investigated. The hydrothermolysis of the rapeseed meal components: the protein, the lignocellulosic and the fat fractions, was carried out in subcritical water at temperatures of $180{ }^{\circ} \mathrm{C}$ to $280^{\circ} \mathrm{C}$ during holding times between 0 and $60 \mathrm{~min}$. The effects of temperature and holding time on the composition of the primary and secondary reaction products present in the water and ether fractions were determined. The highest yield of amino acids $\left(124 \mathrm{~g} \cdot \mathrm{kg}^{-1}\right.$ of rapeseed meal) was obtained at $200{ }^{\circ} \mathrm{C}$ and $60 \mathrm{~min}$. The xylose with the highest yield $\left(35 \mathrm{~g} \cdot \mathrm{kg}^{-1}\right)$ was obtained at $220{ }^{\circ} \mathrm{C}$ and 20 min, and the glucose $\left(51 \mathrm{~g} \cdot \mathrm{kg}^{-1}\right)$ at $260{ }^{\circ} \mathrm{C}$ and $10 \mathrm{~min}$. The highest yield of phenolics was $39 \mathrm{~g} \cdot \mathrm{kg}^{-1}$ at $280{ }^{\circ} \mathrm{C}$ and 60 min. The maximum degree of conversion to free fatty acids was 0.98 at $240{ }^{\circ} \mathrm{C}$ and $60 \mathrm{~min}$.
\end{abstract}

Keywords: rapeseed meal, hydrothermolysis, amino acids, monosaccharides, phenolics, free fatty acids

\section{INTRODUCTION}

Rapeseed (Brassica napus L.) is the most important oil plant in Poland and, in recent years, the production of both rapeseed crops and rapeseed oil for food purposes and as a fuel (biodiesel) for cars with diesel engines has been steadily increasing in Poland. ${ }^{1}$ The consequence of the increasing consumption of rapeseed oil is the increasing amount of its production byproducts: straw, cake and extraction meal. ${ }^{2-4}$

Rapeseed meal, rich in proteins and lignocellulosic components, is a waste product from the extraction of oil from rapeseed. In 2017, the industrial processing of rapeseed in Poland generated about 1.43 million tonnes of rapeseed meal, and in comparison with 2016, the production of rapeseed meal increased by over 60000 tonnes. ${ }^{1}$ Because in 2018 the European Parliament adopted a directive on the promotion of the use of energy from renewable sources (REDII), which the Member States should implement by 30 June 2021, it should be recognized that in the coming years the demand for biodiesel will increase in Poland and thus the production of rapeseed meal will increase. ${ }^{5}$ Also, difficulties can be expected with its traditional agricultural development as a high-protein component used in animal feed.

Until now, only a few attempts have been made at utilizing excess rapeseed meal for purposes other than the traditional one, such as rapeseed meal combustion, complete utilization to produce lipophilic phenolic compounds, protein and monosugars or biotransformation, leading, among other things, to the production of polymers and biosurfactants. ${ }^{6-9}$

In the present study, a thermochemical method for the valorization of rapeseed meal is proposed. This technique, based on the biorefinery concept, consists in hydrothermolysis in subcritical water of the main components contained in rapeseed meal, i.e. protein, hemicellulose, cellulose, lignin and residual amounts of fat, yielding a liquid fraction containing bioproducts - amino acids, saccharides, carboxylic acids, aldehydes (including furfurals), volatile fatty acids, free fatty acids and alkylphenols.

In recent years, various kinds of plant and animal biomass have been subjected to 
hydrothermolysis, but so far comprehensive reports on research on hydrothermal conversion in subcritical water of multicomponent waste biomass containing a protein fraction, a lignocellulosic fraction and a fat fraction, as in the case of rapeseed meal, have been scarce. ${ }^{10-13}$

Recently, only a few works have started developing subcritical water valorization processes of rapeseed meal. Remón et al. explored the possibility of simultaneous production of lignin and polysaccharides by microwave-assisted hydrothermal treatment of rapeseed meal and studied the effect of experimental conditions: the temperature $\left(150-210{ }^{\circ} \mathrm{C}\right)$, reaction time $(0-60 \mathrm{~min})$ and catalyst (acetic acid $1-4 \mathrm{~mol} \cdot \mathrm{L}^{-1}$ ) on the solid and liquid product fractions composition. Under optimal conditions $\left(186{ }^{\circ} \mathrm{C}, 2 \mathrm{~min}, 1 \mathrm{~mol} \cdot \mathrm{L}^{-1}\right)$, the yield of high purity lignin contained in the solid fraction was $85 \mathrm{wt} \%$ and the yield of oligosaccharide rich mixture contained in the liquid phase was $62 \mathrm{wt} \%$. $^{12}$

In our study, exploiting the specific properties of subcritical water and using water as reaction solvent and reagent, in one-stage hydrothermal conversion of a $10 \%(\mathrm{w} / \mathrm{w})$ rapeseed meal suspension, was conducted without the use of any additional catalyst or excipients. The present research was undertaken to explore this process in subcritical water under batch conditions and to determine the effect of the reaction parameters (reaction temperature and duration) on the degree of conversion of the rapeseed meal components.

\section{EXPERIMENTAL}

Materials and chemicals

Rapeseed meal from the Fats \& Oils Manufacturing Plants Kruszwica PLC (Brzeg, Poland), ground to a grain size below $1 \mathrm{~mm}$ and dried to a constant mass at a temperature of $103{ }^{\circ} \mathrm{C}$, was used for the studies.

Mono- and disaccharides (arabinose, xylose, glucose, fructose, galactose, mannose and cellobiose), acetic, lactic and levulinic acids and amino acids were purchased from Fluka, aldehydes (glycolaldehyde, glyceraldehyde and pyruvaldehyde) and furfurals (2furfural and 5-hydroxymethylfurfural), dihydroxyacetone and 1,2,4-benzenetriol, as well as guaiacol, pyrocatechol, phenol, $o$-cresol and $p$-cresol, were purchased from Sigma-Aldrich. Formic acid, diethyl ether and other reagents used in analytical determinations were purchased from POCh (Poland), whereas $m$-cresol was purchased from Roth $\mathrm{GmbH}$ (Germany). Depending on the requirements of the particular analytical method, analytically or HPLC pure reagents were used.

\section{Reactor and experimental procedure}

The dried and ground rapeseed meal was hydrolyzed in a high-temperature, high-pressure Parr 4576A batch reactor (Moline, Illinois, USA), equipped with a $250 \mathrm{~cm}^{3}$ vessel (height: $70 \mathrm{~mm}$, inside diameter: $65 \mathrm{~mm}$ and wall thickness: $15 \mathrm{~mm}$ ) made of stainless steel T316, a magnetic stirrer with a $1700 \mathrm{rpm}$ drive, a manometer, a (single loop) U-tube internal cooler, a heating mantle with a $2.0 \mathrm{~kW}$ electric heater, a fixed head, a reagent dosing valve, a device for taking samples, a thermocouple installed in the reactor vessel, a 4857 apparatus set controlling unit, a 4875 power controller and the CALGrafix software.

The hydrothermolysis of the rapeseed meal was conducted at temperatures of 180, 200, 220, 240, 260 and $280{ }^{\circ} \mathrm{C}$. The reaction was stopped once the intended temperature was reached (zero holding time), and after holding times of 5, 10, 20, 30, 40 and $60 \mathrm{~min}$ under pressure corresponding to the vapor pressure curve at the given temperature, or slightly exceeding it.

Before its use, HPLC pure water was subjected to degassing in an ultrasonic bath and blown through with nitrogen. The reagents were used at a water:rapeseed meal mass ratio of 90:10. The rapeseed meal $(10 \mathrm{~g})$ in water $\left(90 \mathrm{~cm}^{3}\right)$ suspension was introduced into the reaction vessel preheated to about $80{ }^{\circ} \mathrm{C}$. A detailed description of the experimental procedure is given elsewhere. $^{14}$

\section{Separation of rapeseed meal hydrothermolysis products}

The hydrothermal valorization of the rapeseed meal yielded a liquid product and a solid post-reaction residue, which were separated by filtering under reduced pressure through a PTFE membrane filter made by Sartorius (SRP 15, $0.45 \mu \mathrm{m}$ ).

Diethyl ether, in the amount of $100 \mathrm{~cm}^{3}$, was added to the permeate and after hour-long extraction, the top layer was separated from the bottom layer (a WS fraction containing water-soluble substances). In order to remove the diethyl ether, the top layer was dried in a vacuum drier at a temperature of $45^{\circ} \mathrm{C}$, whereby an ES fraction (containing diethyl ether-soluble substances) was obtained. The latter was analyzed for free fatty acid (FFA) content

The bottom layer was diluted with water to a volume of $250 \mathrm{~cm}^{3}$, and its amino acids, saccharides, carboxylic acids, aldehydes (including furfurals), dihydroxyacetone (DHA), 1,2,4-benzenetriol (BTO), phenolic compounds and volatile fatty acids (VFA) content was determined. In all the cases, substance $\mathrm{i}$ content $\mathrm{Y}_{\mathrm{i}}$ in the WS product fractions was calculated from the relation:

$\mathrm{Y}_{\mathrm{i}}(\% \mathrm{w} / \mathrm{w})=\left(\mathrm{m}_{\mathrm{i}} / \mathrm{m}_{\mathrm{rm}}\right) \times 100$

where $m_{i}$ is the mass of the $i$-products contained in the WS fractions $(\mathrm{g})$, and $\mathrm{m}_{\mathrm{rm}}$ is the mass of the rapeseed meal used for the reaction $(\mathrm{g})$.

In the ES fractions, the degree of conversion $\left(\mathrm{Y}_{\mathrm{FFA}}\right)$ 
of the triacylglycerols contained in the rapeseed meal, leading to FFA, was calculated from the formula:

$\mathrm{Y}_{\mathrm{FFA}}=\mathrm{AV}_{\mathrm{i}} / \mathrm{SV}_{\mathrm{rm}}$

where $A V_{i}$ is the acid number determined in the ES fractions, and $\mathrm{SV}_{\mathrm{rm}}$ is the saponification number of the rapeseed meal.

\section{Analysis and analytical methods}

The elementary composition of the rapeseed meal was determined with an experimental error of $\pm 3 \%$, using the Vario EL III apparatus made by Elementar Analysensysteme $\mathrm{GmbH}$.

The composition of the raw material was determined using standard analytical methods for biomass. $^{15-17}$ Except for moisture content determinations, rapeseed meal dried to constant mass was investigated.

The rapeseed meal was also subjected to chromatographic analysis to determine the bound amino acids content. ${ }^{14}$

Also, the FFA content in the rapeseed meal and the selected ES fractions was determined by gas chromatography. In the former case, samples subjected to 24-hour extraction with diethyl ether were investigated. The sample's components were converted into fatty acid methyl esters, and after derivation, the methyl derivatives were determined using a Philips PU 4410 chromatograph with a flame ionization detector. The separation was conducted in a Restek capillary column Rtx-2330 (temperature program $180-220^{\circ} \mathrm{C}$ ).

The acid number of the rapeseed meal $\left(\mathrm{AV}_{\mathrm{rm}}\right)$ and that of the ES fractions and the saponification number of the rapeseed meal were determined. ${ }^{18,19}$

The free amino acids content in the WS fractions was determined by the spectrophotometric ninhydrin method (Spekol 1200, Carl Zeiss Technology, Germany) using L-glutamic acid as the standard substance. ${ }^{20}$ The composition of the amino acids contained in the WS fractions was determined using an Ingos AAA 400 analyzer equipped with a photometric detector. ${ }^{14}$

The saccharides, carboxylic acids, aldehydes (including furfurals), DHA, BTO and phenolics contents in the WS fractions of the rapeseed meal hydrothermal decomposition products were determined using a Merck-Hitachi liquid chromatograph equipped with a Knauer SmartLine 1000 gradient pump.

The saccharides (arabinose, xylose, glucose, fructose, galactose, mannose and cellobiose) contents were determined with an experimental error of $\pm 5 \%$ at a temperature of $85{ }^{\circ} \mathrm{C}$ in a Bio-Rad Aminex HPX-87P column equipped with a precolumn. The operating conditions of the analysis are described elsewhere. ${ }^{21}$

The carboxylic (formic, acetic, lactic) acids contents were determined with an experimental error of $\pm 3 \%$ using a Eurospher C18 (Knauer) column. ${ }^{21}$
The 2-furfural
(2-FA) and the 5hydroxymethylfurfural (5-HMF) contents were determined at a temperature of $35^{\circ} \mathrm{C}$ in a Eurospher C18 column. ${ }^{17}$ Experimental errors are about $5 \%$.

A Shodex KC-811 column was employed to determine the glycolaldehyde, glyceraldehyde and pyruvaldehyde, levulinic acid, DHA, and BTO contents. ${ }^{20}$ Experimental errors are about $\pm 3 \%$.

The guaiacol, pyrocatechol, phenol, $o$-cresol, $m$ cresol and $p$-cresol contents were determined with an experimental error of $\pm 2 \%$ at a temperature of $40{ }^{\circ} \mathrm{C}$ using an Inertsil ODS-3 column (Bujno Chemicals). ${ }^{21}$

The VFA - formic, acetic, propionic, isobutyric, butyric, isopentanoic, and pentanoic acid - content in the WS fractions was determined using a PYE UNICAm series 104 gas chromatograph. ${ }^{14}$ Experimental errors are about 5\%.

All the analytical determinations were performed in triplicate, and the mean values were calculated.

\section{RESULTS AND DISCUSSION Composition of rapeseed meal}

The elementary composition of the rapeseed meal, having the molecular formula $\left[\mathrm{C}_{3.86} \mathrm{H}_{6.02} \mathrm{O}_{2.55} \mathrm{~N}_{0.46} \mathrm{~S}_{0.01}\right]_{\mathrm{n}}$, was as follows: carbon (46.4\%), hydrogen (6.1\%), oxygen (40.8\%), nitrogen $(6.4 \%)$ and sulfur $(0.3 \%)$. The rapeseed meal dry matter content amounted to $86.7 \%$, ash to $7.7 \%$, total protein to $39.8 \%$, diethyl ether extractable substance represented $2.5 \%$, hemicellulose $5.5 \%$, acetyl groups $3.6 \%$, cellulose $15.1 \%$, acid-insoluble lignin $18.5 \%$ and acidsoluble lignin $6.9 \%$. The rapeseed meal's acid number is 11.50 , and its saponification number is 183.52. The density of the rapeseed meal was $0.61 \mathrm{~g} \cdot \mathrm{cm}^{-3}$, and the $\mathrm{pH}$ of the $10 \%(\mathrm{w} / \mathrm{w})$ water slurry was 6.02 .

The rapeseed meal bound amino acid content in $100.0 \mathrm{~g}$ of raw material amounted to $32.2 \mathrm{~g}$. Table 1 shows the composition of the bound amino acids present in the raw material subjected to hydrothermal decomposition. In terms of quantity (a high 5\% share in the amino acid fraction), glutamic acid and aspartic acid predominated, followed by leucine, proline, glycine, arginine, valine, alanine and threonine.

\section{Effect of reaction temperature and time on the yield of amino acids in WS fractions}

Figure 1 shows the effect of the hydrothermolysis temperature and duration on the yield of amino acids in the WS fractions. For the experiments where the reaction was stopped as soon as the chosen temperature was reached, the amino acid yield increased with reaction temperature between 180 and $240{ }^{\circ} \mathrm{C}$. At temperatures of 180 and $200{ }^{\circ} \mathrm{C}$, the yields of 
amino acids also increased with increasing holding time to a maximum value of $12.4 \%$ (200 ${ }^{\circ} \mathrm{C}, 60 \mathrm{~min}$ ). The high ionic product of water under these conditions contributed to the formation of amino acids. $^{20}$ However, the obtained yields of amino acids were lower than by conventional acid hydrolysis since amino acids produced by hydrothermal hydrolysis subsequently degrade. ${ }^{12,22}$ The decrease in the yield of amino acids with further increasing temperature and holding time was due to their progressive deamination, leading to the formation of ammonia and volatile organic acids and decarboxylation yielding carbonic acid and amines. ${ }^{10,12}$ At temperatures of 260 and $280{ }^{\circ} \mathrm{C}$, the yield of amino acids dropped considerably, as the rate of decomposition of amino acids was faster than the rate of hydrolytic depolymerization of the protein fraction in rapeseed meal.

Table 1

Bound amino acid content in rapeseed meal

\begin{tabular}{lc}
\hline $\begin{array}{l}\text { Amino acids } \\
\text { in rapeseed meal }\end{array}$ & $\begin{array}{c}\text { Bound amino acid content in } \\
\text { relation to } 32.2 \mathrm{~g}(\% \mathrm{w} / \mathrm{w})\end{array}$ \\
\hline Alanine & 5.4 \\
Arginine & 5.9 \\
Cysteine & 2.4 \\
Phenylalanine & 4.8 \\
Glycine & 6.2 \\
Histidine & 2.9 \\
Isoleucine & 4.1 \\
Aspartic acid & 8.6 \\
Glutamic acid & 18.8 \\
Leucine & 8.3 \\
Lysine & 3.2 \\
Methionine & 2.2 \\
Proline & 7.2 \\
Serine & 5.0 \\
Threonine & 5.4 \\
Tryptophan & 1.1 \\
Tyrosine & 2.7 \\
Valine & 5.7 \\
\hline
\end{tabular}

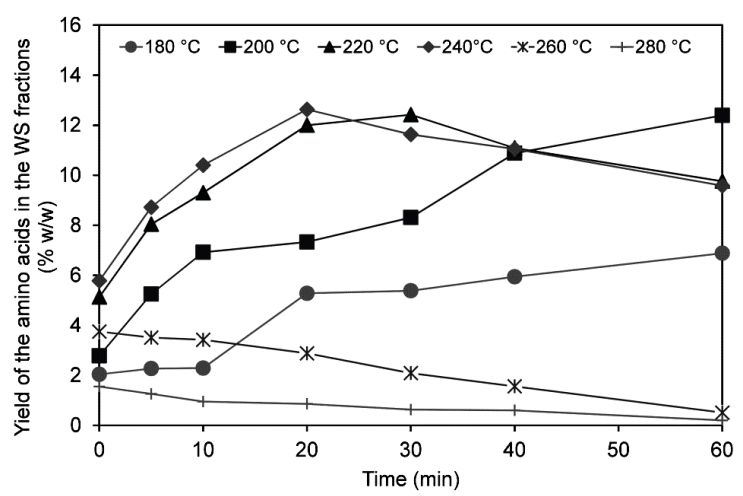

Figure 1: Effect of reaction temperature and time on the yields of amino acids in WS fractions obtained from hydrothermal decomposition of rapeseed meal

The gas product fraction was not analyzed as part of this research. However, the content of some VFAs - such as products of the deamination of amino acids - was determined in selected WS fractions (Table 3). ${ }^{23,24}$ Among the VFAs identified in the WS fractions, the yields of formic acid $\left(1.7 \%, 260{ }^{\circ} \mathrm{C}, 0 \mathrm{~min}\right)$ and acetic acid $(1.9 \%$, $280{ }^{\circ} \mathrm{C}, 60 \mathrm{~min}$ ) were the highest. However, the acids could have been the products of not only the deamination of the amino acids formed as a result 
of the hydrolysis of the protein fraction present in the rapeseed meal, but also of the decomposition of the lignocellulosic fraction components. ${ }^{10,25,26}$ Formic acid could have been formed as a result of the degradation of the furfurals, while acetic acid might have been the product of the abstraction of the acetyl groups contained in the pendant groups of the polymeric chain of the hemicellulose. In the investigated WS fractions, formic acid was contained in different quantitative proportions, showing no clear dependence on the reaction temperature and holding time. The yield of acetic acid slightly increased with both temperature and holding time. The yields of the other VFAs in the WS fraction were negligible $(0.2-0.5 \%)$ and did not show a clear dependence on the temperature and duration of the hydrothermal decomposition of the rapeseed meal.

The low yields of amino acids in the WS fractions could also be due to the Maillard reaction during hydrothermolysis of rapeseed meal, i.e. the condensation reaction of the amine groups of the amino acids or the protein with the carbonyl or the hemiacetal groups present in the oligomer and polymeric carbohydrates, resulting in the formation of melanoidins. ${ }^{10,24,27}$

Table 2

FFA composition and content in rapeseed meal

\begin{tabular}{lr}
\hline FFA & $(\% \mathrm{w} / \mathrm{w})$ \\
\hline Saturated acids & 15.16 \\
C8:0-C15:0 & 0.25 \\
C16:0 & 11.58 \\
C17:0-C24:0 & 3.33 \\
Monoenic acids & 63.14 \\
C16:1n7 & 1.51 \\
C18:1n7 & 18.97 \\
C16:1n9 & 0.12 \\
C18:1n9 & 42.14 \\
C20:1n9 & 0.40 \\
Dienic acids & 18.77 \\
C18:2n6 & 18.77 \\
Polyenic acids & 2.93 \\
C18:3n3 & 2.93 \\
\hline
\end{tabular}

Table 3

Volatile fatty acid profile and yield in selected WS fractions obtained from hydrothermal decomposition of rapeseed meal

\begin{tabular}{lccccccc}
\hline \multirow{2}{*}{$\begin{array}{c}\text { Temperature/time } \\
\left({ }^{\circ} \mathrm{C} / \mathrm{min}\right)\end{array}$} & $\begin{array}{c}\text { Formic } \\
\text { acid }\end{array}$ & $\begin{array}{c}\text { Acetic } \\
\text { acid }\end{array}$ & $\begin{array}{c}\text { Propionic } \\
\text { acid }\end{array}$ & $\begin{array}{c}\text { Isobutyric } \\
\text { acid }\end{array}$ & $\begin{array}{c}\text { Butyric } \\
\text { acid }\end{array}$ & $\begin{array}{c}\text { Isopentanoic } \\
\text { acid }\end{array}$ & $\begin{array}{c}\text { Pentanoic } \\
\text { acid }\end{array}$ \\
\hline $180 / 60$ & 0.51 & 0.43 & 0.03 & 0.02 & 0.07 & 0.03 & 0.05 \\
$200 / 60$ & 0.23 & 0.60 & 0.07 & 0.04 & 0.07 & 0.05 & 0.06 \\
$220 / 60$ & 0.67 & 0.67 & 0.05 & 0.04 & 0.07 & 0.06 & 0.05 \\
$240 / 0$ & 0.64 & 0.70 & 0.04 & 0.05 & 0.06 & 0.04 & 0.05 \\
$240 / 60$ & 0.12 & 0.89 & 0.06 & 0.05 & 0.07 & 0.05 & 0.05 \\
$260 / 0$ & 1.66 & 1.03 & 0.05 & 0.03 & 0.07 & 0.05 & 0.07 \\
$260 / 60$ & 0.13 & 1.15 & 0.08 & 0.03 & 0.08 & 0.07 & 0.08 \\
$280 / 0$ & 0.11 & 1.57 & 0.09 & 0.04 & 0.07 & 0.06 & 0.06 \\
$280 / 60$ & 0.11 & 1.92 & 0.10 & 0.04 & 0.08 & 0.06 & 0.06 \\
\hline
\end{tabular}

\section{Profiles of amino acid contents in WS fractions}

Figure 2 shows the percentage of amino acids in the WS fractions obtained from rapeseed meal hydrothermolysis under different experimental conditions. Similarly to the bound amino acids contained in the rapeseed meal, 18 amino acids were found to be present in the WS fractions. The composition of the amino acids mixture in the WS fractions was different from that of the particular bound amino acids in the rapeseed meal. 
Similarly to the content in the rapeseed meal, the predominating amino acid in all the investigated WS fractions was glutamic acid, whose share in the reaction products increased with reaction temperature, and with holding time at a constant temperature. This is the effect of high thermal stability of glutamic acid due to its additional methylene group in the side chain. ${ }^{28}$ Nevertheless, a further increase in reaction temperature and duration caused degradation of glutamic acid. This compound could undergo, besides deamination and decarboxylation, dimerization to form diketopiperazine and/or dehydration to form

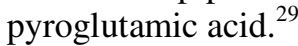

The share of the other amino acids contained in the WS fractions was much smaller (not exceeding 10\%) than that of glutamic acid. The percentage of polar amino acids, such as arginine, aspartic acid, glycine, serine, threonine and tryptophan, decreased with the increase of both reaction temperature and holding time. In contrast, the nonpolar amino acids, such as alanine, leucine, proline and valine, remained stable, and their percentages in the WS fractions increased with temperature, as well as with holding time at a constant temperature, except at a temperature of $280^{\circ} \mathrm{C}$. As a result of the changes taking place in the course of the decomposition of the rapeseed meal protein fraction in subcritical water - deamination, decarboxylation, gasification (with formation of carbon dioxide, carbon monoxide, hydrogen, methane) and other degradation processes with formation of low alkanes, alkenes, alcohols, amides, aldehydes the structure of the amino acids and their share in the WS fractions would change. ${ }^{10,12}$ The changes could also have been due to the decomposition of the less stable amino acids present in the reaction mixture under given conditions, while the other amino acids remained thermally stable..$^{30,31}$

\section{Effect of reaction temperature and time on the yield of hydrothermolysis products of lignocellulosic components in WS fractions}

Table 4 shows the effect of reaction temperature and holding time on the yield of hydrothermolysis products of lignocellulosic components in the WS fractions.

The hydrothermolysis of rapeseed meal under the adopted reaction conditions led to the formation of considerable amounts of primary and secondary reaction products in the WS fractions. Some of the products forming in situ during the hydrothermolysis of hemicellulose, e.g., acetic acid and uronic acids, together with a hydronium ion originating from water dissociation, could catalyze the hydrolysis of hemicellulose and cellulose to saccharides and the dehydration, retro-aldol condensation and regrouping of saccharides to furan derivatives, and to other organic acids (lactic acid, levulinic acid), DHA, BTO and aldehydes. ${ }^{12,25,32-34}$

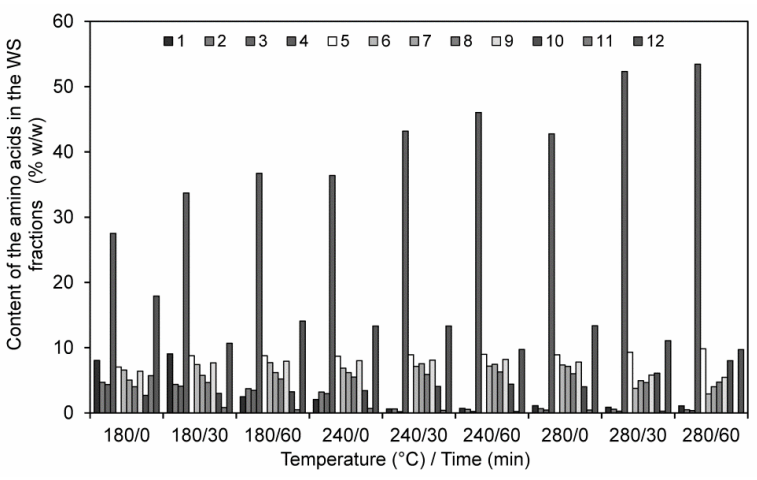

Figure 2: Profiles of amino acids content in WS fractions obtained from hydrothermal decomposition of rapeseed meal under different experimental conditions: 1 - aspartic acid, 2 - threonine, 3 - serine, 4 - glutamic acid, 5 - proline, 6 glycine, 7 - alanine, 8 - valine, 9 - leucine, 10 - tyrosine, 11 - arginine, 12 - other amino acids: isoleucine, phenylalanine, histidine, lysine, cysteine, methionine, tryptophan

The primary products of the hydrolytic depolymerization of hemicellulose and cellulose, i.e. mono- and disaccharides and acetic acid, were found to be present in the WS fractions. These fractions also contained secondary components resulting from the decomposition of primary 
products. Also, the products of the hydrothermolysis of the lignin fraction (phenolics), i.e. pyrocatechol, guaiacol, phenol, $m$-cresol, $p$-cresol and $o$-cresol, were identified in the WS fractions.

Table 4

Contents in WS fractions of products obtained from the hydrothermal decomposition of rapeseed meal

\begin{tabular}{|c|c|c|c|c|c|c|c|c|c|}
\hline \multirow[b]{2}{*}{$\begin{array}{c}\text { Temperature } \\
\left({ }^{\circ} \mathrm{C}\right)\end{array}$} & \multirow[b]{2}{*}{$\begin{array}{l}\text { Holding } \\
\text { time } \\
(\mathrm{min})\end{array}$} & \multicolumn{8}{|c|}{ Yield (\% w/w) } \\
\hline & & Xylose & Glucose & $\begin{array}{c}\text { Other } \\
\text { saccharides }^{1)}\end{array}$ & $\begin{array}{l}\text { Acetic } \\
\text { acid }\end{array}$ & $\begin{array}{c}\text { Other } \\
\text { carboxylic } \\
\text { acids }^{2)}\end{array}$ & Furfurals $^{3)}$ & $\begin{array}{c}\text { Aldehydes }^{4)} \\
+ \text { DHA + } \\
\text { BTO }\end{array}$ & Phenolics ${ }^{5)}$ \\
\hline \multirow{7}{*}{180} & 0 & 0.0 & 0.1 & 0.1 & 0.0 & 0.1 & 0.0 & 0.0 & 0.3 \\
\hline & 5 & 0.1 & 0.1 & 0.1 & 0.0 & 0.2 & 0.0 & 0.0 & 0.4 \\
\hline & 10 & 0.1 & 0.1 & 0.2 & 0.1 & 0.3 & 0.0 & 0.0 & 0.4 \\
\hline & 20 & 0.4 & 0.1 & 0.3 & 0.1 & 0.2 & 0.0 & 0.0 & 0.5 \\
\hline & 30 & 0.4 & 0.1 & 0.4 & 0.2 & 0.3 & 0.0 & 0.0 & 0.5 \\
\hline & 40 & 0.5 & 0.1 & 0.4 & 0.2 & 0.3 & 0.1 & 0.0 & 0.8 \\
\hline & 60 & 0.7 & 0.2 & 0.5 & 0.3 & 0.4 & 0.2 & 0.1 & 0.8 \\
\hline \multirow{7}{*}{200} & 0 & 0.1 & 0.1 & 0.1 & 0.1 & 0.1 & 0.0 & 0.1 & 0.5 \\
\hline & 5 & 0.2 & 0.1 & 0.2 & 0.2 & 0.3 & 0.0 & 0.1 & 0.7 \\
\hline & 10 & 0.4 & 0.1 & 0.3 & 0.2 & 0.3 & 0.0 & 0.1 & 0.7 \\
\hline & 20 & 0.6 & 0.2 & 0.4 & 0.3 & 0.4 & 0.1 & 0.1 & 1.0 \\
\hline & 30 & 0.7 & 0.2 & 0.4 & 0.4 & 0.4 & 0.1 & 0.2 & 1.7 \\
\hline & 40 & 0.8 & 0.4 & 0.4 & 0.5 & 0.5 & 0.2 & 0.2 & 1.8 \\
\hline & 60 & 1.0 & 0.5 & 0.5 & 0.6 & 0.6 & 0.4 & 0.2 & 2.1 \\
\hline \multirow{7}{*}{220} & 0 & 0.5 & 0.2 & 0.1 & 0.1 & 0.2 & 0.1 & 0.1 & 0.5 \\
\hline & 5 & 0.8 & 0.3 & 0.3 & 0.2 & 0.2 & 0.1 & 0.1 & 0.8 \\
\hline & 10 & 1.8 & 0.4 & 0.4 & 0.4 & 0.4 & 0.2 & 0.2 & 1.0 \\
\hline & 20 & 3.5 & 0.4 & 0.4 & 0.5 & 0.4 & 0.2 & 0.1 & 1.1 \\
\hline & 30 & 2.6 & 0.6 & 0.4 & 0.5 & 0.6 & 0.2 & 0.2 & 2.3 \\
\hline & 40 & 2.2 & 0.8 & 0.5 & 0.6 & 0.7 & 0.2 & 0.2 & 2.6 \\
\hline & 60 & 1.1 & 1.0 & 0.5 & 0.6 & 0.8 & 0.3 & 0.3 & 3.0 \\
\hline \multirow{7}{*}{240} & 0 & 0.6 & 0.3 & 0.2 & 0.7 & 0.3 & 0.1 & 0.1 & 1.4 \\
\hline & 5 & 0.4 & 0.5 & 0.3 & 0.7 & 0.4 & 0.2 & 0.1 & 1.3 \\
\hline & 10 & 0.3 & 0.6 & 0.4 & 0.8 & 0.6 & 0.3 & 0.1 & 1.6 \\
\hline & 20 & 0.2 & 0.9 & 0.5 & 0.8 & 0.7 & 0.3 & 0.2 & 1.8 \\
\hline & 30 & 0.2 & 1.1 & 0.5 & 0.8 & 0.9 & 0.4 & 0.2 & 2.7 \\
\hline & 40 & 0.1 & 1.3 & 0.6 & 0.9 & 1.0 & 0.4 & 0.4 & 3.1 \\
\hline & 60 & 0.0 & 1.7 & 0.6 & 0.9 & 1.1 & 0.4 & 0.4 & 3.4 \\
\hline \multirow{7}{*}{260} & 0 & 0.1 & 0.4 & 0.2 & 0.8 & 0.4 & 0.3 & 0.2 & 1.4 \\
\hline & 5 & 0.2 & 2.5 & 0.4 & 0.8 & 0.5 & 0.4 & 0.2 & 1.8 \\
\hline & 10 & 0.1 & 5.1 & 0.6 & 0.9 & 0.6 & 0.4 & 0.3 & 1.9 \\
\hline & 20 & 0.1 & 3.0 & 0.7 & 1.0 & 0.7 & 0.5 & 0.4 & 2.2 \\
\hline & 30 & 0.0 & 1.3 & 0.7 & 1.1 & 0.7 & 0.5 & 0.4 & 2.7 \\
\hline & 40 & 0.0 & 1.8 & 0.8 & 1.3 & 1.1 & 0.7 & 0.5 & 3.1 \\
\hline & 60 & 0.0 & 0.3 & 0.9 & 1.5 & 1.3 & 0.6 & 0.6 & 3.6 \\
\hline \multirow{7}{*}{280} & 0 & 0.1 & 0.9 & 0.5 & 1.6 & 0.5 & 0.3 & 0.2 & 1.5 \\
\hline & 5 & 0.1 & 0.6 & 0.7 & 1.6 & 0.6 & 0.5 & 0.3 & 1.8 \\
\hline & 10 & 0.0 & 0.6 & 0.9 & 1.7 & 0.8 & 0.5 & 0.6 & 2.1 \\
\hline & 20 & 0.0 & 0.3 & 1.2 & 1.7 & 0.9 & 0.6 & 0.6 & 2.2 \\
\hline & 30 & 0.0 & 0.2 & 0.5 & 1.8 & 1.0 & 0.7 & 0.7 & 2.2 \\
\hline & 40 & 0.0 & 0.2 & 0.1 & 1.8 & 1.1 & 0.8 & 0.8 & 3.6 \\
\hline & 60 & 0.0 & 0.0 & 0.0 & 1.9 & 1.4 & 0.9 & 0.9 & 3.9 \\
\hline
\end{tabular}

glyceraldehyde, pyruvaldehyde; ${ }^{5)}$ guaiacol, pyrocatechol, phenol, $o$-cresol, $m$-cresol, $p$-cresol

At lower reaction temperatures $\left(180-220{ }^{\circ} \mathrm{C}\right)$ and shorter holding times (0-20 min), xylose, the product of the hydrolytic depolymerization of hemicellulose, predominated in the WS fractions. With increasing reaction temperatures (240-260 $\left.{ }^{\circ} \mathrm{C}\right)$, glucose, the primary product of hydrothermolysis of cellulose, was also detected and it isomerized into fructose via the LBAE (Lobry de Bruyn-Alberda van Ekenstein) transformation. ${ }^{22}$ Further increase in reaction 
temperature and holding time resulted in the decomposition of xylose $\left(240-280{ }^{\circ} \mathrm{C}, 0-60 \mathrm{~min}\right)$, glucose and fructose $\left(280{ }^{\circ} \mathrm{C}, 5-60 \mathrm{~min}\right)$ and the secondary reaction products, such as carboxylic acids, aldehydes, DHA and BTO, were also found in the WS fractions. Under such reaction conditions, the degradation rate of saccharides was higher than the rate of hemicellulose and cellulose hydrothermal depolymerization. ${ }^{25}$

Carboxylic acids, except acetic acid (resulting from the cleavage of acetyl groups contained in the side chains of the hemicellulose), were products of the degradation of saccharides. For example, lactic acid was a product of the rearrangement and dehydration of pyruvaldehyde formed from the dehydration of glyceraldehyde obtained from the retro-aldol condensation of glucose and/or fructose..$^{21,32,33}$ Levulinic acid, in turn, was a product of the degradation of 5-HMF from a sequence of reactions starting with hydration of the furan ring, tautomerization and dehydration reactions. ${ }^{33}$ The yield of carboxylic acids regularly increased with reaction temperature, but did not exceed $3.3 \%$, even at 280 ${ }^{\circ} \mathrm{C}$ after $60 \mathrm{~min}$.

Small amounts of furfurals, 2-FA and 5-HMF, which were formed as products of the dehydration of respectively xylose and glucose and its isomer fructose, other aldehydes and DHA and BTO, were detected in the WS fractions. ${ }^{32,33}$ The glycolaldehyde could have been formed as a result of the condensation of the pentoses: xylose and arabinose, or the retro-aldol condensation of the erythrose formed from glucose. ${ }^{25,32}$ Another product of the retro-aldol condensation of the pentoses and the hexoses was glyceraldehyde..$^{25,32,33}$ Glyceraldehyde could be dehydrated to form pyruvaldehyde, while the product obtained by the intramolecular rearrangement of the glyceraldehyde was DHA. ${ }^{25,32,33}$ BTO was converted from 5-HMF through the hydrolysis of its furan ring, tautomerization, an aldol-like reaction, and dehydration. 32,33

The yield of phenolic products in the WS fractions obtained by the hydrothermal decomposition of the lignin component contained in the rapeseed meal increased with temperature and holding time. The primary product of the hydrothermolysis of lignin was guaiacol, a lignin monomer that was formed as a result of its hydrolysis (the cleavage of $\mathrm{C}-\mathrm{O}$ linkages in lignin). Pyrocatechol was formed from the dealkylation of lignin or guaiacol as a result of its demethoxylation. ${ }^{31}$ Phenol and $o$-cresol, $m$-cresol and $p$-cresol were the secondary reaction products obtained by the decomposition of guaiacol or by the hydrolysis of pyrocatechol. ${ }^{34-36}$ The yields of phenol, $o$-cresol, $m$-cresol, and $p$-cresol increased gradually in the investigated temperature and holding time ranges, but under the experimental conditions used, the phenol and cresols yields did not directly correspond to the changes in the guaiacol or pyrocatechol contents (probably due to the gasification of some of the products of lignin decomposition during the reaction). ${ }^{36}$

\section{Effect of reaction temperature and time on the yield of fatty acids in ES fractions}

Figure 3 shows the effect of temperature and holding time on the yield of FFA in ES fractions formed as a result of the hydrothermolysis of the triacylglycerols contained in the rapeseed meal. The period of induction (typical of conventional hydrolysis processes), due to the limited solubility of water in oil, was inconspicuous. When it was over, and FFA appeared in the reaction medium, the conversion of triacylglycerols abruptly increased almost linearly.

At temperatures of $180,200,220$ and $240{ }^{\circ} \mathrm{C}$, the FFA yield increased with temperature and holding time, reaching 0.98 at a temperature 240 ${ }^{\circ} \mathrm{C}$ and a holding time of $60 \mathrm{~min}$. At 260 and 280 ${ }^{\circ} \mathrm{C}$, the FFA yield increased with reaction temperature and initially with holding time (respectively $0-30 \mathrm{~min}$ and $0 \mathrm{~min}$ ). Further holding the reaction mixture at the set temperature caused a marked fall in the FFA yield, probably because of the thermal degradation of the reaction mixture components, i.e., the triacylglycerols present in the rapeseed meal or FFA. ${ }^{37,38}$ Additionally, at the adopted temperature and holding time, the FFA may have undergone polymerization. ${ }^{39}$

Table 5 shows the profile and the share of the FFA contained in selected ES fractions obtained from the hydrolysis of the rapeseed meal subjected to hydrothermal decomposition. The majority of saturated acids were stable under the chosen conditions. In contrast, the main unsaturated fatty acids contained in rapeseed meal, oleic and linoleic acids, underwent cis-trans isomerization (which does not occur for acids produced under conventional industrial hydrolysis procedures), which depended on the reaction temperature and holding time. In the course of the hydrothermal decomposition of the rapeseed 
meal, the total content of the trans isomers of oleic acid and linoleic acid increased with both temperature and time, reaching $10.6 \%$ after 60 min at a temperature of $280{ }^{\circ} \mathrm{C}$.

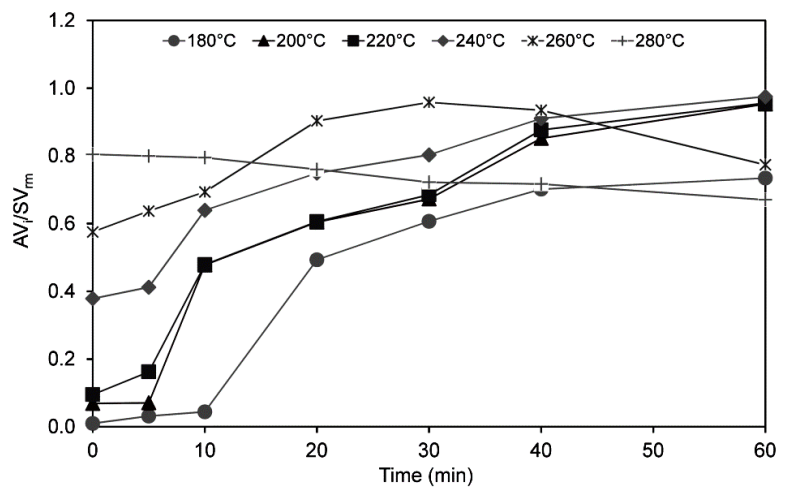

Figure 3: Effect of reaction temperature and holding time on fatty acids yield in ES fractions obtained from hydrothermal decomposition of rapeseed meal

Table 5

Profile and content of fatty acids in selected ES fractions obtained from hydrothermal decomposition of rapeseed meal

\begin{tabular}{lrrrrrrrrr}
\hline \multirow{2}{*}{ FFA $(\%$ w/w) } & \multicolumn{8}{c}{ Reaction temperature $\left({ }^{\circ} \mathrm{C}\right) /$ holding time $(\mathrm{min})$} \\
\cline { 2 - 11 } & $180 / 0$ & $180 / 30$ & $180 / 60$ & $240 / 0$ & $240 / 30$ & $240 / 60$ & $280 / 0$ & $280 / 30$ & $280 / 60$ \\
\hline Saturated acids (C8:0-C24:0) & 15.13 & 14.86 & 14.42 & 15.00 & 14.88 & 14.49 & 14.78 & 14.23 & 14.13 \\
C16:0 & 11.32 & 11.48 & 11.45 & 11.16 & 11.10 & 11.06 & 11.06 & 11.17 & 11.05 \\
Trans isomers & 1.28 & 1.55 & 2.30 & 5.34 & 6.28 & 7.94 & 8.02 & 9.12 & 10.55 \\
C18:1 & 0.75 & 0.82 & 1.51 & 4.98 & 5.05 & 6.73 & 5.13 & 6.90 & 8.55 \\
C18:2 & 0.53 & 0.73 & 0.79 & 1.36 & 1.23 & 1.21 & 2.89 & 2.22 & 2.00 \\
Monoenic acids & 20.41 & 21.07 & 21.68 & 21.50 & 21.25 & 21.44 & 20.72 & 21.12 & 20.31 \\
C16: 1n7 & 1.46 & 1.42 & 1.44 & 1.32 & 1.28 & 1.24 & 1.23 & 1.19 & 1.03 \\
C18:1n7 & 18.95 & 19.65 & 20.24 & 20.18 & 19.97 & 20.20 & 19.49 & 19.93 & 19.28 \\
Monoenic acids & 43.51 & 43.31 & 43.11 & 40.26 & 39.67 & 38.83 & 39.74 & 38.78 & 38.64 \\
C16:1n9 & 1.42 & 1.17 & 0.48 & 0.90 & 0.64 & 0.47 & 0.72 & 0.55 & 0.20 \\
C18:1n9 & 42.09 & 42.14 & 42.63 & 39.36 & 39.03 & 38.36 & 39.02 & 38.23 & 38.44 \\
Dienic acids & 18.20 & 18.02 & 17.87 & 17.34 & 17.43 & 17.26 & 15.99 & 16.10 & 15.78 \\
C18:2n6 & 18.20 & 18.02 & 17.87 & 17.34 & 17.43 & 17.26 & 15.99 & 16.10 & 15.78 \\
Polyenic acids & 1.47 & 1.19 & 0.62 & 0.56 & 0.49 & 0.04 & 0.75 & 0.65 & 0.59 \\
C18:3n3 & 1.47 & 1.19 & 0.62 & 0.56 & 0.49 & 0.04 & 0.75 & 0.65 & 0.59 \\
\hline
\end{tabular}

\section{CONCLUSION}

We have investigated the hydrothermolysis of $10 \%(\mathrm{w} / \mathrm{w})$ rapeseed meal suspensions in subcritical water, where the subcritical water performed the functions of reagent, solvent, and acid catalyst of the process.

The WS fractions obtained as a result of the hydrothermolysis procedure consisted of a mixture of products, with amino acids being the quantitatively dominant components. The yield of amino acids showed optimal values equal to approximately $124 \mathrm{~g} \cdot \mathrm{kg}^{-1}$ of rapeseed meal at a reaction temperature of $200{ }^{\circ} \mathrm{C}$ and a long holding time of $60 \mathrm{~min}$.

The maximum region for the xylose yield ( 35 $\left.\mathrm{g} \cdot \mathrm{kg}^{-1}\right)$ was found at slightly higher temperatures $\left(220{ }^{\circ} \mathrm{C}\right)$, but shorter holding times $(20 \mathrm{~min})$, whereas the optimal yield of glucose $\left(51 \mathrm{~g} \cdot \mathrm{kg}^{-1}\right)$ required significantly higher temperature $\left(260^{\circ} \mathrm{C}\right)$ and even shorter reaction times (10 min).

The phenolics were minor reaction products, but their yield increased together with the holding time, reaching $39 \mathrm{~g} \cdot \mathrm{kg}^{-1}$ at $280{ }^{\circ} \mathrm{C}$ and a reaction time of $60 \mathrm{~min}$. 
The conversion of triacylglycerols to free fatty acids increased with reaction temperature (especially up to $240{ }^{\circ} \mathrm{C}$ ) and holding time (up to $60 \mathrm{~min}$ ), but high reaction temperature and excessively long holding time caused a reduction in the degree of conversion. The structure and content of free fatty acids in the ES fractions differed from the profile of the free fatty acids present in the rapeseed meal, and at the same time, the geometry of the configuration of unsaturated fatty acids changed in the course of the hydrolysis.

The highest reaction temperatures and times investigated enhanced secondary undesirable degradation reactions of primary reaction products.

The products obtained in the hydrothermolysis process of the rapeseed meal, corresponding to the concept of agro-bio-refineries and oleo-biorefineries, after isolation and appropriate physicochemical treatment, may have commercial importance and may be used for the production of chemicals, transportation fuels, and energy.

Under the applied reaction conditions, the hydrothermolysis of the protein, hemicellulose and cellulose contained in rapeseed meal aimed at acquiring amino acids and monosaccharides is an attractive proposition. However, the acquisition of carboxylic acids, aldehydes (including furfurals), phenolics, and free fatty acids is not a viable alternative to the existing solutions.

The effectiveness of the hydrothermal conversion of the quantitatively dominant components contained in rapeseed meal could be ensured by conducting this process in three stages. Rapeseed meal would be the raw material for the first stage whose aim would be the hydrolysis of the protein contained in the rapeseed meal. The solid post-reaction residue from the first stage would be used in the second stage of the hydrothermolysis to produce xylose. The solid post-reaction residue from the second stage would be the feedstock feeding the reactor in the third stage of the hydrothermal conversion, whose aim would be to optimize the production of glucose.

\section{REFERENCES}

1 http://www.portalspozywczy.pl/zboza/wiadomosci/ pspo-wyprodukowalismy-niemal-1-5-mln-ton-pasz-

rzepakowych-w-2017-r,155937.html (accessed 05.2019) (in Polish)

2 F. Potůček and M. Milichovský, Cellulose Chem. Technol., $\quad \mathbf{4 5}, \quad 23 \quad$ (2011), http://www.cellulosechemtechnol.ro/pdf/CCT12(2011)/p.23-28.pdf
3 I. Deykun, V. Haysh and V. Barbash, Cellulose Chem. Technol., 52, $833 \quad$ (2018), http://www.cellulosechemtechnol.ro/pdf/CCT910(2018)/p.833-839.pdf

4 A. Boldrin, A. Balzan and T. Astrup, Biomass Convers. Biorefin., 3, $127 \quad$ (2013), https://doi.org/10.1007/s13399-013-0071-9

5 http://www.kib.pl (accessed 05.2019) (in Polish)

6 G. Eriksson, H. Hedman, D. Boström, E. Pettersson, R. Backman et al., Energ. Fuel., 23, 3930 (2009), https://doi.org/10.1021/ef900308r

7 D. Boström, G. Eriksson, C. Boman and M. Öhman, Energ. Fuel., 23, 2700 (2009), https://doi.org/10.1021/ef800965b

8 J. Li and Z. Guo, ACS Sustain. Chem. Eng., 5, 6218 (2017),

https://doi.org/10.1021/acssuschemeng.7b01171

9 D. Konkola, I. Szmigiel, M. Domżał-Kędzia, M. Kułażyński, A. Krasowanka et al., Bioorg. Chem., https://doi.org/10.1016/j.bioorg.2019.03.039

10 I. Pavlovič, Ž. Knez and M. Škerget, J. Agric. Food. Chem., 61, $8003 \quad$ (2013), https://doi.org/10.1021/jf401008a

11 Ž. Knez, M. Knez Hrnčič, M. Čolnik and M. Škerget, J. Supercrit. Fluid., 133, 591 (2018), https://dx.doi.org/10.1016/j.supflu.2017.08.011

12 J. Remón, A. S. Matharu and J. H. Clark, Energ. Convers. Manage., 165, $634 \quad$ (2018), https://doi.org/10.1016/j.enconman.2018.03.091

13 Z. W. Wang, M. Q. Zhu, M. F. Li, J. Q. Wang and R. C. Sun, Biotechnol. Biofuels, 9, 142 (2016), https://doi: 10.1186/s13068-016-0552-8

14 H. Pińkowska, P. Wolak and E. Oliveros, Biomass Bioenerg., $\quad 64, \quad 51 \quad$ (2014), https://doi.org/10.1016/j.biombioe.2014.03.028

15 NFTA, The National Forage Testing Association, Laboratory procedures, Omaha, USA, https://www.foragetesting.org/lab-procedures (accessed 05.2019)

16 NREL, The National Renewable Energy Laboratory, Chemical Analysis and testing. Laboratory analytical procedures. Golden, CO, USA, https://www.nrel.gov/bioenergy/biomass-

compositional-analysis.html (accessed 05.2019)

17 P. J. Van Soest, J. B. Robertson and B. A. Lewis, J. Dairy Sci., 74, $3583 \quad$ (1991), https://doi.org/10.3168/jds.S0022-0302(91)78551-2

18 Standard test method for acid value of fatty acids and polymerized fatty acids, ASTM D1980-87 (1998) (in Polish)

19 Standard test method for determination of the saponification value of fats and oils, ASTM D5558-95 (2006) (in Polish)

${ }^{20}$ K. Watchararuji, M. Goto, M. Sasaki and A. Shotipruk, Bioresour. Technol., 99, 6207 (2008), https://doi: 10.1016/j.biortech.2007.12.021 
H. Pińkowska, P. Wolak and E. Oliveros, Biomass Bioenerg., 58, 188 (2013), https://doi.org/10.1016/j.biombioe.2013.09.005

22 A. A. Peterson, F. Vogel, R. P. Lachance, M. Fröling, M. J. Antal et al., Energ. Environ. Sci., 1, 32 (2008), https://doi.org/10.1039/B810100K

23 M. Goto, R. Obuchi, T. Hirose, T. Sakaki and M. Shibata, Bioresour. Technol., 93, 279 (2004), https://doi.org/10.1016/j.biortech.2003.11.017

24 J. Yang, Q. S. He and L. Yang, Appl. Energ., 250, 926 (2019),

https://doi.org/10.1016/j.apenergy.2019.05.033

25 Y. Yu, X. Lou and H. Wu, Energ. Fuel., 22, 46 (2008), https://doi.org/10.1021/ef700292p

26 O. Pourali, F. S. Asghari and H. Yoshida, Food Chem.,

115 ,

1

(2009), https://doi.org/10.1016/j.foodchem.2008.11.099

27 A. A. Peterson, R. P. Lachance and J. W. Tester, Ind. Eng. Chem. Res., 49, 2107 (2010), https://doi.org/10.1021/ie9014809

28 M. Sohn and C. T. Ho, J. Agric. Food Chem., 43, 3001 (1995), https://doi.org/10.1021/jf00060a001

29 R. S. Nunes and E. T. G. Cavalheiro, J. Therm. Anal. Calorim., 87, $627 \quad$ (2007), https://doi.org/10.1007/s10973-006-7788-7

30 T. Rogalinski, S. Herrmann and G. Brunner, J. Supercrit. Fluid., 36, 49, (2005), https://doi.org/10.1016/j.supflu.2005.03.001
31 W. Abdelmoez, T. Nakahasi and H. Yoshida, Ind. Eng. Chem. Res., 46, $5286 \quad$ (2007), https://doi.org/10.1021/ie070151b

32 T. M. Aida, Y. Sato, M. Watanabe, K. Tajima, T. Nonaka et al., J. Supercrit. Fluid., 40, 381 (2007), https://doi.org/10.1016/j.supflu.2006.07.027

33 T. M. Aida, K. Tajima, M. Watanabe, Y. Saito, K. Kuroda et al., J. Supercrit. Fluid., 42, 110 (2007), http://doi.org/10.1016/j.supflu.2006.12.017

34 Wahyudiono, M. Sasaki and M. Goto, J. Mater. Cycles Waste Manag., 13, 68 (2011), https://doi.org/10.1007/s10163-010-0309-6

35 K. Okuda, S. Ohara, M. Umetsu, S. Takami and T. Adschiri, Bioresour. Technol., 99, 1846 (2008), https://doi.org/10.1016/j.biortech.2007.03.062

36 Wahyudiono, M. Sasaki and M. Goto, Chem. Eng. $\begin{array}{llll}\text { Process., } & 47, & 1609 & \text { (2008), }\end{array}$ https://doi.org/10.1016/j.cep.2007.09.001

37 R. L. Holliday, J. W. King and G. R. List, Ind. Eng. Chem. Res., 36, $932 \quad$ (1997) https://doi.org/10.1021/ie960668f

38 O. Tavakoli and H. Yoshida, Ind. Eng. Chem. Res., 45, 5675 (2006), https://doi.org/10.1021/ie0513806

39 W. He, G. Li, L. Kong, H. Wang, J. Huang et al., Resour. Conserv. Recyc., 52, 691 (2008), https://doi.org/10.1016/j.resconrec.2007.11.003 